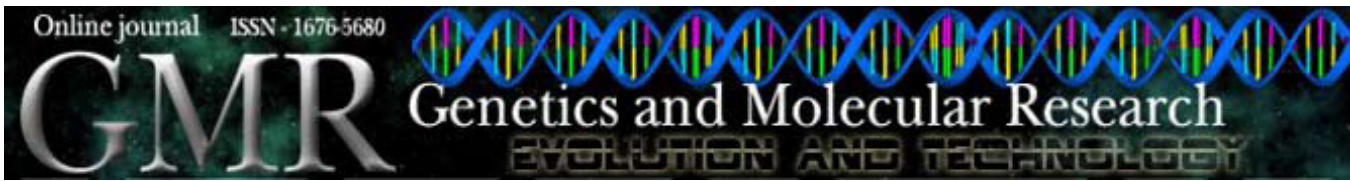

\title{
Modulatory effect of Byrsonima verbascifolia (Malpighiaceae) against damage induced by doxorubicin in somatic cells of Drosophila melanogaster
}

D.M. Mendanha ${ }^{1}$, H.D. Ferreira ${ }^{1}$, L.P. Felício ${ }^{1}$, E.M. Silva ${ }^{2}$, D.G. Pereira ${ }^{3}$, W.B. Nunes $^{2}$ and S. Carvalho ${ }^{1}$

${ }^{1}$ Instituto de Ciências Biológicas, Departamento de Biologia Geral, Universidade Federal de Goiás, Goiânia, GO, Brasil

2Instituto de Ciências Biológicas, Departamento de Morfologia, Universidade Federal de Goiás, Goiânia, GO, Brasil

${ }^{3}$ Departamento de Biologia, Faculdade Estácio de Sá, Goiânia, GO, Brasil

Corresponding author: S. Carvalho

E-mail: salvadorcarvalho2005@yahoo.com.br

Genet. Mol. Res. 9 (1): 69-77 (2010)

Received August 24, 2009

Accepted October 19, 2009

Published January 19, 2010

\begin{abstract}
Byrsonima verbascifolia, popularly known in Brazil as murici, is a medicinal plant widely used in the treatment of bacterial and viral infections, Chagas's disease, diarrhea, bronchitis, cough and fever, as well as for protection of the intestinal mucosa. Since chemotherapy and radiotherapy, broadly employed in the treatment of cancer, can have undesirable side effects, such as inducing DNA damage in normal cells, it would be useful to investigate compounds that inhibit or reduce these effects. A lyophilized water extract of murici, used at three different concentrations $(25,50$, and $100 \mathrm{mg} / \mathrm{mL}$ ), was tested to determine if it could reduce damage induced by the antineoplastic compound doxorubicin in somatic cells of Drosophila melanogaster, analyzed by SMART/wing. The frequency of mutant spots in descendants from standard and high bioactivation crosses was significantly reduced by treatment with murici extract. Further studies are needed using other experimental
\end{abstract}


models, to determine if murici has the potential to be employed by cancer patients receiving chemotherapy.

Key words: Byrsonima verbascifolia; Drosophila melanogaster; SMART/wing; Murici; Anti-genotoxicity

\section{INTRODUCTION}

The use of medicinal plants in folk medicine is based on empirical knowledge gathered for centuries by different ethnic groups. The idea is ancient: treating or preventing diseases using parts of plants prepared in various different ways or using the active principles extracted from them. This empirical knowledge, which has been acquired over long periods of time based on daily experiences and passed down from generation to generation, constitutes the origin of modern medicine.

Byrsonima verbascifolia (L.) Rich. ex A. L. Juss is a medicinal plant, popularly known in Brazil as "murici", "douradinha-falsa", "mirici", "muricizinho", "orelha-de-burro", "orelha-de-veado", "semaneira", and "baga-de-tucano". It belongs to the family Malpighiacea and the genus Byrsonima, distributed all over tropical America, with approximately 150 species, from which 60 can be found in Brazil (Mamede, 1982). Murici is predominantly found in the Brazilian Cerrado, distributed in Distrito Federal and in the States of Alagoas, Amazonas, Bahia, Goiás, Mato Grosso, Mato Grosso do Sul, Minas Gerais, Pará, Paraná, São Paulo, and Tocantins, and blooms from August to October (Batista et al., 2005). This species has edible sour-sweet fruits, which are consumed in a variety of ways, ranging from the fresh fruit to processed products such as sweets, liquor, juice, ice cream, popsicle, and jam (Almeida, 1998). Furthermore, it has forage potential and can be used in the tanning industry due to its astringent properties, its wood is used in construction, and all parts of the plant are popularly utilized in the treatment of various diseases (Lorenzi and Matos, 2002).

The infusion prepared with $B$. verbascifolia leaves is widely utilized to treat diarrhea and intestinal infections, and also to protect the intestinal mucosa. An infusion of its roots is recommended in the treatment of chronic wounds, Chagas's disease, afflictions of the oral cavity and throat, using local application, as well as against infections of the female genital tract (Panizza, 1998). The bark of this plant has laxative, astringent, and antipyretic properties. When the fruit is eaten with sugar, it works as a mild laxative and can also be used in the treatment of cough and bronchitis (Almeida et al., 1998). Several species of the genus Byrsonima are generally used as antipyretic agents and also to treat skin infections and asthma (Cáceres et al., 1993). Experiments using B. verbascifolia leaf and root extracts demonstrated their antiviral activity against herpes (Lopez et al., 2001) and antimicrobial and antiviral effects in general, as well as lack of cytotoxicity (Khan et al., 2005).

Chemical analyses of $B$. verbascifolia revealed the presence of triterpenoids in the bark (Almeida et al., 1998) and tannins, flavonoids, triterpenes, aromatic esters, naphthoquinones, and amentoflavone in the leaves (Sannomiya et al., 2004), which proves that this species has a variety of phytotherapeutical components.

The isolated principles have been associated with the treatment of several illnesses. Tannins are considered to be good enzyme inducers and are also broadly used for their venotropic action (increased resistance of veins and small vessels) and hemostatic, antimicrobial, antiviral, anti-inflammatory, hypoglycemic, and antispasmodic properties (Silva et al., 1995), as well as 
in cases of diarrhea (Almeida et al., 1998; Tridente, 2002). Flavonoids are recommended for their anti-inflammatory, diuretic, antimicrobial, fungicidal, and antiviral actions. Triterpenoids possess a number of medicinal properties, such as anti-inflammatory, antibacterial, antifungal, antiviral, analgesic, cardiovascular, and antitumor characteristics (Mendes, 2004).

The cytotoxic and antigenotoxic assessment of $B$. verbascifolia and other plant extracts is extremely important because they constitute very attractive sources of compounds that can be used in the development of novel pharmaceutical products (Simões et al., 2000). Therefore, studies on the safety of continuous use of these species by people and on measures to preserve them in their natural habitat are highly important.

In the present study, we chose Drosophila melanogaster as the test organism, which allows the development of fast and reliable assays, to assess the modulatory effect of the water extract of $B$. verbascifolia (WEB), since this insect shows several advantages, such as being a eukaryotic organism with a short generation time (approximately 10 days at $25^{\circ} \mathrm{C}$ ), easily detected morphologic characteristics, great number of isolated mutants, a mapped genome, and good development in low-cost culture medium (Graf et al., 1992).

The somatic mutation and recombination test (SMART/wing) allows the detection of genetic mutations, chromosome aberrations, and genetic recombinations caused by direct- and/ or indirect-acting genotoxins (Caldeira, 2008). This assay is based on the fact that, during early embryonic development of $D$. melanogaster, imaginal disc cells proliferate mitotically to form structures that, during larval development up to differentiation in the metamorphosis phase, will become the wings in the body of the adult fly (Costa and Nepomuceno, 2003). When a genetic alteration takes place in a wing imaginal disc cell, it will be present in all the descendant cells, forming a clone of mutant cells detected as a spot of mutant hair on the adult fly wing (Ito et al., 1997).

The present study aimed at assessing the cytotoxic potential of WEB as well as its possible modulatory effect when combined with doxorubicin (DXR) in standard (ST) and high bioactivation (HB) crosses using the SMART assay of D. melanogaster.

\section{MATERIAL AND METHODS}

\section{Plant material}

Leaves of $B$. verbascifolia were collected in an area of Cerrado sensu stricto in the municipality of Anápolis, State of Goiás, Brazil, in August 2007, and identified by Prof. Heleno Dias Ferreira, Department of Botany of the Universidade Federal de Goiás. A voucher specimen $($ No. 27,624) was deposited in the herbarium of the Universidade Federal de Goiás.

In order to obtain WEB, B. verbascifolia leaves were dried and ground in a mortar, after which an infusion was prepared, lyophilized, and stored in screw-cap vials in an ordinary refrigerator.

WEB was used to generate the survival curves at concentrations of $10,20,30,40,50,60$, $70,80,90,100$, and $120 \mathrm{mg} / \mathrm{mL}$, prepared from the lyophilized extract dissolved in distilled water. For the antimutagenesis experiments, we used three different concentrations of WEB $(25,50$, and $100 \mathrm{mg} / \mathrm{mL}$ ) obtained by dissolving the lyophilized extract in distilled water at the time of use.

\section{Doxorubicin}

DXR (Doxolen lyophilized, Eurofarma Laboratórios Ltda., São Paulo, Brazil, CAS 
No. 23214-92-8) dissolved in distilled water in the dark at a concentration of $0.125 \mathrm{mg} / \mathrm{mL}$ was used as positive control and distilled water as negative control.

\section{Survival curve}

To determine the cytotoxic potential of WEB, eleven different concentrations were prepared in triplicate $(10,20,30,40,50,60,70,80,90,100$, and $120 \mathrm{mg} / \mathrm{mL})$ by dissolving the lyophilized extract in distilled water at the time of treating $D$. melanogaster third-stage larvae. We used exactly 100 larvae/concentration and the emergent adults were recorded. The results were compared to the negative control.

\section{Somatic mutation and recombination test}

\section{Drosophila strains and crosses}

Three strains of $D$. melanogaster were used: a) multiple wing hairs: $y$; $m w h j$ (mwh,

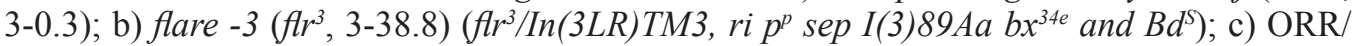

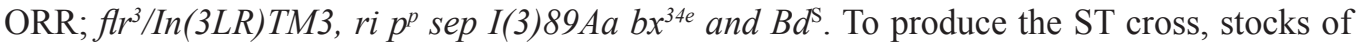
flare-3 werw virgin females were crossed with stocks of mwh males (Graf et al., 1989). The HB cross, which has high levels of cytochrome P450, was obtained by crossing ORR; flare-3 werw virgin females with mwh males (Graf and van Schaik, 1992).

Both crosses produced experimental larval progeny that consisted of marker-heterozygous $(\mathrm{MH})$ flies (mwh $+/+$ flare-3) with phenotypically wild-type wings and balancer-heterozygous flies (mwh +/+ TM3 Bd ${ }^{\mathrm{s}}$ ) with phenotypically serrate wings (Saner et al., 1996).

\section{Larval feeding}

Eggs from the ST and HB crosses were collected over an 8-h period and maintained in culture bottles containing a solid agar base $(3 \%, \mathrm{w} / \mathrm{v})$ covered with a layer of live baker's yeast (Saccharomyces cerevisiae) supplemented with sucrose. For the treatments, 72-h-old larvae were removed from the culture bottles and washed in tap water with the help of a fine mesh stainless steel strainer.

The larvae from both crosses were transferred to glass tubes containing $0.9 \mathrm{~g}$ synthetic medium (form 4-24, Carolina Biological Supply Co., Burlington, USA) dissolved in $3.0 \mathrm{~mL}$ of a solution containing WEB with or without $0.125 \mathrm{mg} / \mathrm{mL}$ DXR, which is a concentration known to be genotoxic to $D$. melanogaster somatic cells. The results obtained for the antimutagenesis assay (WEB + DXR) were compared to that of the positive control $(0.125 \mathrm{mg} / \mathrm{mL}$ DXR). Since some of the compounds are photosensitive, all the tubes were wrapped in aluminum foil. The larvae were fed on the medium until their larval life was complete ( 2 days). The experiments were performed at $25^{\circ} \mathrm{C}$ and relative humidity of $60 \%$.

\section{Analysis of adult flies}

After hatching, individual adult flies were collected and stored in $70 \%$ ethanol. The wings of MH flies were removed, mounted in Faure's solution, and examined for spots us- 
ing a compound microscope at $400 \mathrm{X}$ magnification. During the analysis, the positions of the spots were recorded according to wing sections (Graf et al., 1984). Single spots resulted from point mutations, chromosome aberrations, or recombination events, while twin spots (flare and mwh) were produced by mitotic recombination between the proximal marker flare and the centromere of chromosome 3 .

\section{Statistical analysis}

The frequencies of each type of spot for each treatment group were compared pairwise (DXR vs each WEB + DXR group), using the Mann-Whitney nonparametric U-test and the Wilcoxon rank sum text (Frei and Würgler, 1995). We calculated WEB percent inhibition using the mutant clone frequency/105 cells corrected by the control group (Abraham, 1994).

\section{RESULTS}

The survival curves shown in Figure 1 present data on the cytotoxic potential of WEB with the percentage of individuals that survived in ST and HB crosses. Although the doses chosen in the present study were higher than those commonly used, our results show that the number of individuals that survived, compared to the negative control, was not statistically significant in either cross (ST and HB).

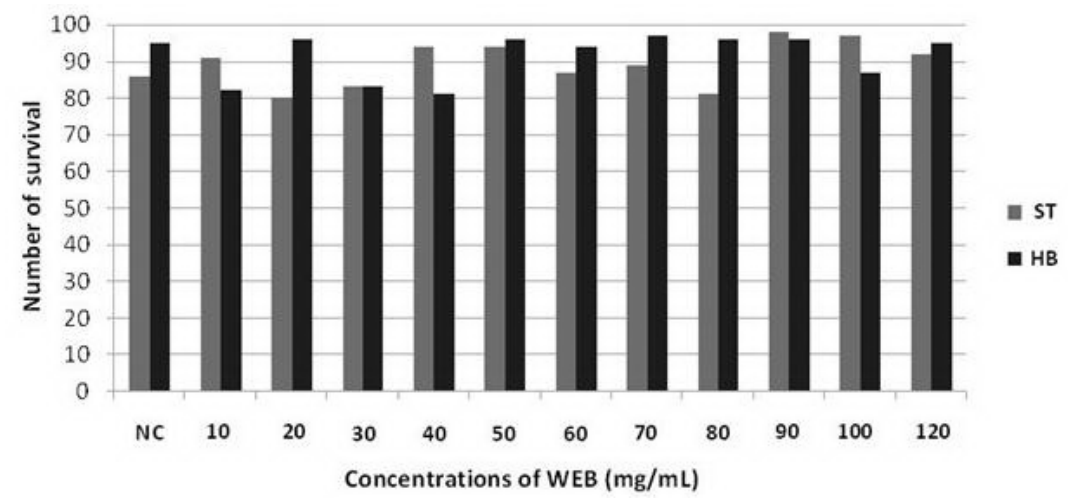

Figure 1. Survival curves of Drosophila melanogaster standard (ST) and high bioactivation (HB) cross descendants fed different concentrations $(10,20,30,40,50,60,70,80,90,100$, and $120 \mathrm{mg} / \mathrm{mL})$ of water extract of Byrsonima verbascifolia $(\mathrm{WEB}) . \mathrm{NC}=$ negative control.

The antigenotoxic results of WEB in combination with DXR, obtained through the analysis of MH (trans-heterozigous) descendants from ST and HB crosses, are presented in Table 1. We observed a significant decrease $(\alpha=\beta=0.05)$ in the frequency of simple small spots, simple big spots, twin spots, and total spots compared to the positive control in both crosses (Frei and Würgler, 1995). ST cross showed a dose-dependent reduction in the number of spots at the concentrations of 25 and $100 \mathrm{mg} / \mathrm{mL}$, but not at $50 \mathrm{mg} / \mathrm{mL}$ when considering simple big spots; nevertheless, when considering total spots, the reduction was dose-depen- 
dent at a concentration of $50 \mathrm{mg} / \mathrm{mL}$. HB crosses exhibited dose-dependent reduction in the number of spots at the concentrations of 25 and $50 \mathrm{mg} / \mathrm{mL}$, but not at $100 \mathrm{mg} / \mathrm{mL}$ when considering simple small spots; as observed for ST crosses, there was dose-dependent reduction at $100 \mathrm{mg} / \mathrm{mL}$ only when considering total spots.

Table 1. Frequency of mutant spots observed in marker-heterozygous trans-heterozygous descendants of Drosophila melanogaster from standard (ST) and high bioactivation (HB) crosses treated with three different concentrations $(25,50$, and $100 \mathrm{mg} / \mathrm{mL})$ of water extract of Byrsonima verbascifolia.

\begin{tabular}{|c|c|c|c|c|c|}
\hline \multirow[t]{2}{*}{ Treatment } & \multirow[t]{2}{*}{ Individuals (No.) } & \multicolumn{4}{|c|}{ Frequency of mutant spots per individual (No. of spots) ${ }^{1}$} \\
\hline & & SSS $(1-2$ cells $), m=2$ & SBS $(>2$ cells $), m=5$ & TWS, $\mathrm{m}=5$ & TOS, $\mathrm{m}=2$ \\
\hline \multicolumn{6}{|l|}{ ST cross } \\
\hline Negative control & 20 & $6.80(136)$ & $3.25(65)$ & $2.50(50)$ & $12.55(251)$ \\
\hline $25 \mathrm{mg} / \mathrm{mL}$ & 60 & $1.55(93) \downarrow$ & $0.85(51) \downarrow$ & $0.75(45) \downarrow$ & $3.15(189) \downarrow$ \\
\hline $50 \mathrm{mg} / \mathrm{mL}$ & 60 & $0.67(40) \downarrow$ & $0.13(08) \downarrow$ & $0.23(14) \downarrow$ & $1.03(62) \downarrow$ \\
\hline $100 \mathrm{mg} / \mathrm{mL}$ & 60 & $0.43(26) \downarrow$ & $0.23(14) \downarrow$ & $0.17(10) \downarrow$ & $0.83(50) \downarrow$ \\
\hline \multicolumn{6}{|l|}{ HB cross } \\
\hline Negative control & 20 & $3.20(64)$ & $3.10(62)$ & $3.00(60)$ & $9.30(186)$ \\
\hline $25 \mathrm{mg} / \mathrm{mL}$ & 60 & $0.95(57) \downarrow$ & $0.20(12) \downarrow$ & $0.22(13) \downarrow$ & $1.37(82) \downarrow$ \\
\hline $50 \mathrm{mg} / \mathrm{mL}$ & 60 & $0.63(38) \downarrow$ & $0.22(13) \downarrow$ & $0.28(17) \downarrow$ & $1.13(68) \downarrow$ \\
\hline $100 \mathrm{mg} / \mathrm{mL}$ & 60 & $0.77(46) \downarrow$ & $0.07(04) \downarrow$ & $0.07(04) \downarrow$ & $0.90(54) \downarrow$ \\
\hline
\end{tabular}

${ }^{1}$ Statistical diagnosis according to Frei and Würgler (1988): $\downarrow$ frequency reduction of mutant spots; (m) multiplication factor; $\chi^{2}$ test, two-tailed, to compare proportions. Significance level: $\alpha=\beta=0.05$. SSS $=$ simple small spots; SBS $=$ simple big spots; TWS $=$ twin spots; TOS $=$ total spots.

\section{DISCUSSION}

Larvae treated with WEB + DXR showed a statistically significant decrease in the frequency of simple small spots, simple big spots, twin spots, and total spots compared to the positive control (DXR) in both crosses (ST and HB), demonstrating that WEB exhibited modulatory action against damage induced by DXR in somatic cells of $D$. melanogaster.

The frequency of total spots in the negative control of HB crosses was slightly higher than that observed for ST crosses (Table 1), a result that is in accordance with what was expected, since the frequency of spontaneous spots found in HB crosses is generally higher than that detected for ST crosses (Nunes, 2004; Passos, 2008).

For MH descendants, the positive control displayed a statistically significant increased frequency of mutant spots for all categories when compared to the negative control. These results corroborate the validity of this test.

It is known that DXR has cytotoxic effects during its transformation into semiquinone free radicals, which causes cell death induced by DNA damage (Caldeira, 2008). Although radiotherapy and chemotherapy are aimed at destroying cancer cells, they can also affect healthy cells (Pereira et al., 2008).

The simultaneous use of compounds that are able to modulate the genotoxic effects of chemical and physical agents without interfering in their genotoxic action against neoplastic cells is of great interest to prevent genetic alterations in healthy cells and, consequently, the occurrence of new diseases (Leite et al., 2006). Free radical scavengers, flavonoids, terpenoids, and tannins found in "murici" leaves may account for such a protective action (Goh and Barlow, 2002; Nunes, 2004). 
WEB has certain compounds, such as some polyphenols (flavonoids) and phenolic compounds (tannins and terpenes), which can modulate the genotoxicity of other substances. In the last few decades, several studies have proven that antioxidant agents significantly reduce the genotoxicity of compounds that generate free radicals, especially those induced by antineoplastic drugs (Miranda-Vilela et al., 2008). Béliveau and Gingras (2007) affirm that polyphenols have the ideal chemical structure to absorb free radicals and are therefore more powerful antioxidant agents than vitamins; furthermore, Pimenta and Nepomuceno (2005) reported the antitumor activity of triterpenoids.

The modulatory activity of WEB is likely attributed to the action of its constituents, among which are the tannins. Previous studies have demonstrated that tannins suppress chromosome aberrations induced by a variety of mutagenic agents (Sasaki et al., 1988). Recent studies have shown that various classes of tannins are free radical scavengers that turn them into more stable compounds (Simões et al., 2000; Costa et al., 2006). Thus, tannins are likely to neutralize DXR-free radicals, which are genotoxic (Costa et al., 2005).

Our results showed the protective effect of WEB and are in accordance with those reported in other studies that also demonstrated the protective effect of certain medicinal plants that contain the same chemical constituents. Nunes (2004) found that the aqueous extract of Ginkgo biloba, which contains terpenes and flavonoids, showed protective activity when testing somatic mutation and recombination in D. melanogaster. Using the same procedure, Passos (2008) observed a protective effect of the aqueous extract of Palicourea coriacea. Vilar (2002) reported the protective effect of Annona crassiflora Mart., assessed by the Ames test, due to the presence of polyphenols and tannins. Coelho (2007) observed a modulatory effect of Duguetia furfuracea both in Salmonella typhimurium strains and in somatic cells of Drosophila melanogaster. Agostini et al. (1995) reported the presence of alkaloids, carotenoids and acetogenins, as well as vitamins B1, B2, and C, in species belonging to the family Annonaceae.

According to these results, we believe that WEB is a dismutagenic agent that, when combined with DXR, may perform its protective action by scavenging free radicals due to DXR induction and/or because it blocks the interaction of DXR and free radicals with DNA.

Considering $D$. melanogaster as the test model and the experimental conditions described herein, it is possible to conclude that: DXR $(0.125 \mathrm{mg} / \mathrm{mL})$ is a highly genotoxic agent in both crosses tested (ST and HB); WEB is not cytotoxic at the doses employed to generate the survival curves $(10,20,30,40,50,60,70,80,90,100$, and $120 \mathrm{mg} / \mathrm{mL})$; WEB is a dismutagenic agent that may have antimutagenic, clastogenic, and anti-recombinogenic effects against the oxidative damage induced by DXR.

The presence of certain compounds such as tannins, flavonoids, and terpenoids in "murici" may protect cells against DNA damage (Silva et al., 2006), and they are likely to be responsible for the modulatory effect of this phytotherapeutical agent. Nonetheless, further experiments using other models should be carried out to confirm these results, elucidate the mechanisms used to modulate genotoxic effects, and determine the ideal conditions to use $B$. verbascifolia extracts so that they do not pose any risks to human health.

\section{ACKNOWLEDGMENTS}

Research supported by Instituto de Ciências Biológicas of the Universidade Federal de Goiás. Dr. Cirano José Uchoa prepared the murici lyophilized extract. 


\section{REFERENCES}

Abraham SK (1994). Antigenotoxicity of coffee in the Drosophila assay for somatic mutation and recombination. Mutagenesis 9: 383-386.

Agostini T, Cecchi H and Barrera-Arellano D (1995). Chemical characterization of the oil and pulp of marolo (Annona coriaceae). [Caracterização química da polpa e do óleo do marolo (Annona coriaceae)]. Arch. Latinoam. Nutr. 45: 237-241.

Almeida SP (1998). Cerrado: Aproveitamento Alimentar. EMBRAPA-CPAC, Planaltina.

Almeida SP, Proença CE, Sano SM and Ribeiro JF (1998). Cerrado: Espécies Vegetais Úteis. 1st edn. EMBRAPA-CPAC, Planaltina.

Batista JA, Pacheco MFJ and Santos ML (2005). Biologia reprodutiva de três espécies de Byrsonima Rich. ex Kunth (Malpighiaceae) em um cerrado sensu stricto no campus da Universidade Estadual de Goiás, Anápolis, Goiás, Brasil. Rev. Biol. Neotrop. 2: 109-122.

Béliveau R and Gingras D (2007). Os Alimentos Contra o Câncer: A Prevenção e o Tratamento do Câncer pela Alimentação. Vozes, Petrópolis.

Cáceres A, Figueroa L, Taracena AM and Samayoa B (1993). Plants used in Guatemala for the treatment of respiratory diseases. 2: Evaluation of activity of 16 plants against Gram-positive bacteria. J. Ethnopharmacol. 39: 77-82.

Caldeira K (2008). Avaliação Citotóxica, Genotóxica e Moduladora do Anorexígeno Dietilpropiona em Células Somáticas de Drosophila melanogaster: SMART/wing. Master's thesis, Instituto de Ciências Biológicas, Universidade Federal de Goiás, Goiânia.

Coelho LS (2007). Acción Moduladora de la Genotoxicidad de la Planta Medicinal Duguetia furfuracea (St. Hil) Benth. \& Hook f. em Células Somáticas y Germinativas de Drosophila melanogaster y em Cepas de Salmonella typhimurium. Doctoral thesis, Departamento de Biología Celular y Anatomía, Universidade de Léon, Léon.

Costa HMS, Rabelo CCP, Morais MMC, Coelho LCBB, et al. (2006). Lectins, Tannins and Antimicrobial Activity in Anacardeaceae Barks. Anais da $35^{\text {a }}$ Reunião Anual da Sociedade Brasileira de Bioquímica e Biologia Molecular, Águas de Lindóia.

Costa PM, Ferreira HD, Ferri PH and Guillo LA (2005). Ação moduladora da genotoxicidade da Solanum lycocarpum St. Hil. em micronúcleos induzidos pela ciclofosfamida. Rev. Biol. Neotrop. 2: 43-48.

Costa WF and Nepomuceno JC (2003). Protective effect of the tea of sun mushroom (Agaricus blazei Murill) against genetoxic action of urethane on somatic cells of Drosophila melanogaster. [Efeito protetor do chá de cogumelo do sol (Agaricus blazei Murill) contra a ação genotóxica do uretano em células somáticas de Drosophila melanogaster]. Rev. Cienc. Farm. 24: 153-158.

Frei H and Würgler FE (1988). Statistical methods to decide whether mutagenicity test data from Drosophila assays indicate a positive, negative, or inconclusive result. Mutat. Res. 203: 297-308.

Frei H and Würgler FE (1995). Optimal experimental design and sample size for the statistical evaluation of data from somatic mutation and recombination tests (SMART) in Drosophila. Mutat. Res. 334: 247-258.

Goh LM and Barlow PJ (2002). Antioxidant capacity in Ginkgo biloba. Food Res. Int. 35: 815-820.

Graf U and van Schaik N (1992). Improved high bioactivation cross for the wing somatic mutation and recombination test in Drosophila melanogaster. Mutat. Res. 271: 59-67.

Graf U, Wurgler FE, Katz AJ, Frei H, et al. (1984). Somatic mutation and recombination test in Drosophila melanogaster. Environ. Mutagen. 6: 153-188.

Graf U, Frei H, Kagi A, Katz AJ, et al. (1989). Thirty compounds tested in the Drosophila wing spot test. Mutat. Res. 222: 359-373.

Graf U, Heo OS and Ramirez OO (1992). The genotoxicity of chromium(VI) oxide in the wing spot test of Drosophila melanogaster is over $90 \%$ due to mitotic recombination. Mutat. Res. 266: 197-203.

Ito H, Shimura K, Itoh H and Kawade M (1997). Antitumor effects of a new polysaccharide-protein complex (ATOM) prepared from Agaricus blazei (Iwade strain 101) "Himematsutake" and its mechanisms in tumor-bearing mice. Anticancer Res. 17: 277-284.

Khan MT, Ather A, Thompson KD and Gambari R (2005). Extracts and molecules from medicinal plants against herpes simplex viruses. Antiviral Res. 67: 107-119.

Leite KR, Andrade LS, Sena JS and Vilar JB (2006). Avaliação da atividade mutagênica e genotóxica de Ginkgo biloba L. pelo teste do micronúcleo em camundongos. Rev. Biol. Neotrop. 3: 157-162.

Lopez A, Hudson JB and Towers GH (2001). Antiviral and antimicrobial activities of Colombian medicinal plants. $J$. Ethnopharmacol. 77: 189-196.

Lorenzi H and Matos FJA (2002). Plantas Medicinais no Brasil: Nativas e Exóticas Cultivadas. Instituto Plantarum, Nova Odessa. 
Mamede MCH (1982). Malpighiaceae. Flora Fanerogâmica da Serra do Cipó, Minas Gerais, Brasil. XXXIII Congresso Nacional de Botânica, Alagoas.

Mendes CLA (2004). Triterpenóides e a sua Actividade Anti-Inflamatória. Faculdade de Ciências e Tecnologias da Universidade Nova de Lisboa, Lisboa.

Miranda-Vilela AL, Resck IS and Grisolia CK (2008). Antigenotoxic activity and antioxidant properties of organic and aqueous extracts of pequi fruit (Caryocar brasiliense Camb.) pulp. Genet. Mol. Biol. 31: 956-963.

Nunes WB (2004). Efeito Modulador do Extrato Padronizado de Ginkgo biloba (EGb 761) Contra Mutação e Recombinação Somáticas Induzidas pela Doxorrubicina em Células Somáticas de Drosophila melanogaster. Doctoral thesis, Universidade Federal de Uberlândia, Uberlândia.

Panizza S (1998). Plantas que Curam: Cheiro de Mato. 3rd edn. IBRASA, São Paulo.

Passos DCS (2008). Efeito Modulador do Extrato Aquoso de Palicourea coriacea (Cham.) K. Chum. Contra Mutação e Recombinação Somática Induzida pela Doxorrubicina em Células Somáticas de Drosophila melanogaster. Master's thesis, Instituto de Ciências Biológicas, Universidade Federal de Goiás, Goiânia.

Pereira DG, Antunes LMG, Graf U and Spanó MA (2008). Protection by Panax ginseng C.A. Meyer against the genotoxicity of doxorubicin in somatic cells of Drosophila melanogaster. Genet. Mol. Biol. 31: 947-955.

Pimenta VM and Nepomuceno JC (2005). Genotoxicity testing of Plantago major extracts in somatic cells of Drosophila melanogaster. Environ. Mol. Mutagen. 45: 56-61.

Saner C, Weibel B, Wurgler FE and Sengstag C (1996). Metabolism of promutagens catalyzed by Drosophila melanogaster CYP6A2 enzyme in Saccharomyces cerevisiae. Environ. Mol. Mutagen. 27: 46-58.

Sannomiya M, Rodrigues CM, Coelho RG, Dos Santos LC, et al. (2004). Application of preparative high-speed countercurrent chromatography for the separation of flavonoids from the leaves of Byrsonima crassa Niedenzu (IK). $J$. Chromatogr. A 1035: 47-51.

Sasaki YF, Imanishi H, Ohta T and Watanabe M (1988). Suppressing effect of tannic acid on UV and chemically induced chromosome aberrations in cultured mammalian cells (biological chemistry). Agric. Biol. Chem. 52: 2423-2428.

Silva CJ, Ferreira HD, Ferri PH, Nunes WB, et al. (2006). Ausência de atividade mutagênica de Guazuma ulmifolia Lamb. (mutamba) em células somáticas de Drosophila melanogaster. Rev. Biol. Neotrop. 3: 163-168.

Silva I, Franco SL, Molinari SL and Conegero CI (1995). Noções Sobre o Organismo Humano e Utilização de Plantas Medicinais. 4th edn. Assoeste, Cascavel.

Simões CMO, Schenkel EP, Gosmann G and Mello JCP (2000). Farmacognosia: da Planta ao Medicamento. 2nd edn. Universidade Federal de Santa Catarina, Florianópolis.

Tridente RD (2002). O Uso de Plantas Medicinais na Cidade de Porangatu, Estado de Goiás. Universidade Federal de Goiás, Goiânia.

Vilar JB (2002). Avaliação da Atividade Mutagênica e Antimutagênica de Annona crassiflora Mart. (araticum) pelo Teste de Ames. Graduation paper, Instituto de Ciências Biológicas, Universidade Federal de Goiás, Goiânia. 